more clearly laid out set of definitions would have been a considerable help. Having found them, there is a new category 'of special concern', for which there is no really satisfactory definitionhowever, my personal view is that it would be far better for all RDBs to abandon categories-some of which appear to be tautological anyway.

Another comment concerns maps; although the descriptions of range are a real tour-de-force, a map certainly concentrates the mind. For my money (and I am sure that the reason for the lack of maps is a lack of money), I would have (sadly) foregone Norman Arlott's excellent colour plates-there are, after all, plenty of pictures of pink pigeons - for a distribution of each species.

Of all RDBs so far published, this is certainly the most detailed and comprehensive. This is partly explained by the fact that there are a lot of data available for birds, but is also a reflection on the extent of the research and enthusiasm of the compilers. I have already purchased my own personal copy (so the review copy will be on the FFPS shelves) and I would urge all dedicated (and even dilettanté) conservationists to buy one. Congratulations ICBP!

John A. Burton

\section{A Century of Natural History}

Edited by J.C. Daniel

Bombay Natural History Society, Hombill House, Shahid

Bhagat, Singh Road, Bombay 400023, India, 1983, Rs 150. plus Rs 55 surface mail postage.

This book is a compilation to commemorate the centenary of the Bombay Natural History Society. It consists of selected articles from that Society's famous journal, with an Authors' Index and a Subject Index. The articles cover a variety of subjects: mammals to marine shells, botany, sport and Indian history.

The book is a magnificent volume for fireside reading by those of us who knew India between the two Great Wars, for it gives enthralling (and unintended) glimpses into life in India under the Raj that are not obtainable anywhere else. I found the following articles especially interesting: The Mogul Emperors of India as Naturalists and Sportsmen, by Salim Ali; The Climate of India by S.K. Banerji; and Vanishing and Extinct Birds of India by S. Dillon Ripley.
It is strange that reptiles have such a short section-only 10 pages. The common cobra is not even mentioned.

The book must be handled carefully, for the cover is not 'man enough' for its job.

Strongly recommended.

C.L. Boyle, former Secretary to the FFPS and Editor of Oryx

\section{The 1983 International Zoo Yearbook} Edited by P.J.S. Olney

Zoological Society of London, 1984, HB £26.50 PB $£ 19.50$

After 23 years of publishing to ever increasing standards of excellence, it is difficult to write anything original about the Intemational Zoo Yearbook. Volume 23 is primarily devoted to birds of prey, with the main emphasis on captivebreeding and its role in conservation. The standard of papers is high, and the wide range of subject matter will interest the field ornithologist as well as the zoo specialist.

As usual, there is a section on New Developments in the Zoo World. Papers include several first breedings, as well as more general husbandry topics. Finally, there is the section that most readers have come to depend on: the Reference Section listing species bred in captivity, the Census of Rare and Endangered species held in the world's zoos, and the list of studbooks.

John A. Burton

\section{A Dictionary of Birds}

Edited by B. Campbell and E. Lack

T. and A.D. Poyser (and Buteo in US) 1985, £39.00

This is a complete revision of Landsborough Thomson's long out-of-print New Dictionary of Birds. It is a distillation of erudition from over 280 specialists covering all fields of bird biology. The alphabetically arranged entries range from brief definitions to essays of several thousand words on major topics. Even if the volume is too expensive for many private bookshelves (although good value for over one million words), it should be in all libraries as a primary source of reference.

Robert Burton, Naturalist and Author 